\title{
Decidophobia - an Artistic Research on the Possibilities of Immersive Environments
}

\section{Decidofobia - una investigación artística sobre las posibilidades de entornos inmersivos}

Elke E. Reinhuber

Assistant Professor for Expanded Photography

(School of Art, Design and Media/NTU Singapore)

Fecha de recepción: 1 de junio de 2014

Fecha de revisión: 13 de julio de 2014

Para citar este artículo: Reinhuber, E. E. (2014): Decidophobia - an Artistic Research on the Possibilities of Immersive Environments, Icono 14, volumen (12), pp. 206-229. doi: 10.7195/ri14.v12i2.714 


\section{Abstract}

With the panoramic video installation Decidophobia, I endeavour to point to the difficulty of making decisions and the confrontation with overwhelming choices in our satiated society of today, with the means of media arts. I aim to raise the awareness for the great gift we have: The freedom to choose in many situations of life; but as well being overwhelmed and hindered by an extensive choice and the difficult task of making the right decision. This finally might raise counterfactual thoughts, the retrospective considerations of what would be today, if we decided differently at a turning point at an earlier stage of our life.

In this work, the viewer is confronted with the difficulty of choice. A perfect labyrinth is all around, no orientation is possible, paths appear and disappear again, vanish completely, but new possibilities open up. The soundtrack underlines the visual experience: passers-by are expressing their confusion by questioning where they actually are, where they should go to, which path to take and where they came from. A Babel-like chatter in nine different languages from different directions enhances the confusion. It is difficult to focus on one voice, on a familiar language, which leaves the viewer with the impression of a missed conversation, a missed opportunity.

Key Words: Media Arts - Expanded Photography - Spatial Audio - Immersive Environments - Choice - Decision Making - Counterfactual Thinking - Counterfactualism - Immersion - $360^{\circ}$ environment

\section{Resumen}

Con la instalación de vídeo panorámica Decidofobia, la autora ha tratado de plasmar la dificultad de tomar decisiones y el enfrentamiento con clientes en la sociedad actual, donde el Media Art busca elevar la conciencia por el gran don que tenemos: la libertad de elegir en muchas situaciones de la vida; pero también se puede ser abrumado y obstaculizado por una extensa selección y la difícil tarea de tomar la decisión correcta. Esto último podría aumentar pensamientos contrafactuales, las consideraciones retrospectivas sobre lo que sería hoy en día,

ICONO14 | Año 2014 Volumen 12 № 2 | ISSN: 1697-8293 | DOI: ri14.v12i2.714 
si nos decidimos de forma diferente en un punto de inflexión en una etapa más temprana de nuestra vida.

En esta obra, el espectador se enfrenta a la dificultad de la elección. Un laberinto perfecto está por todas partes, no es posible la orientación, las rutas aparecen y desaparecen de nuevo, desaparecen por completo, pero se abren nuevas posibilidades. La banda sonora subraya la experiencia visual: los transeúntes están expresando su confusión al cuestionar lo que realmente son, a dónde deben ir, qué camino tomar y de dónde venían. Se trata de una charla de Babel como en nueve idiomas diferentes desde distintas direcciones aumenta la confusión. Es dificil concentrarse en una sola voz, en un lenguaje familiar, lo que deja al espectador con la impresión de una conversación perdida, una oportunidad perdida.

Palabras clave: Media Arts - Fotografía Expandida - Audio espacial - Entornos inmersivos - Elección - Toma de decisiones - Pensamiento contrafactual - Contrafractualismo - Inmersión - Ambiente $360^{\circ}$

\section{Introduction}

The choices we now have, in almost all aspects of life, can be overwhelming. We are born in a particular place, into a particular family, with a specific gender, and at a certain astrological conjunction, where our parents, in light of their specific status within their community and their religious convictions, chose our names. From there on, we can change, at least theoretically, nearly all the factors shaping our lives. To be independent and change what can seem to be a predestined life takes strong will, energy, clear decisions and, in particular, freedom. Art gives us the chance to explore these possibilities in theory as well as in practice.

In my artistic research, I endeavour to explore possible life paths and also assume a critical stance of simply accepting fate instead of exercising the freedom of choice, being aware that this privilege cannot be taken for granted by everyone. To achieve this, I used photographic self-portraits and performances-to-camera, and reacted in most of my work to my cultural environment.

DOI: ri14.v12i2.714 | ISSN: 1697-8293 | Año 2014 Volumen 12 № 2 | ICONO14 
Keeping this background in mind, I attempt to address an unknown audience in the immersive audio-visual installation Decidophobia, and to immerse these spectators in an otherworldly, yet at the same time commonplace, experience, raising the awareness that we do have choices in our live. Further, the work is a way to explore counterfactual thoughts: the retrospective considerations of possible alternatives after a turning point in life. In the following paper, I use the term 'counterfactualism', which I introduced in my media arts PhD thesis, to summarise the research on counterfactual thoughts in relevant disciplines and expand it to include the fine $\operatorname{arts}^{1}$. The concept of counterfactuals is already recognised in historiography ${ }^{2}$, philosophy ${ }^{3}$, physics ${ }^{4}$, and in the discipline I consider to be the most important for my research, psychology ${ }^{5}$. What they all have in common is a desire to review turning points and evaluate consequences, not only because of regret for a decision or an outcome, but from curiosity and the desire to imagine possible alternatives. By doing so, the actual result is reinforced.

In this context, I endeavour to give an insight into my practice-based artistic research, rather than discuss the topic in a theoretical framework. Although it is based on theoretical studies, the research resulted in a piece of art.

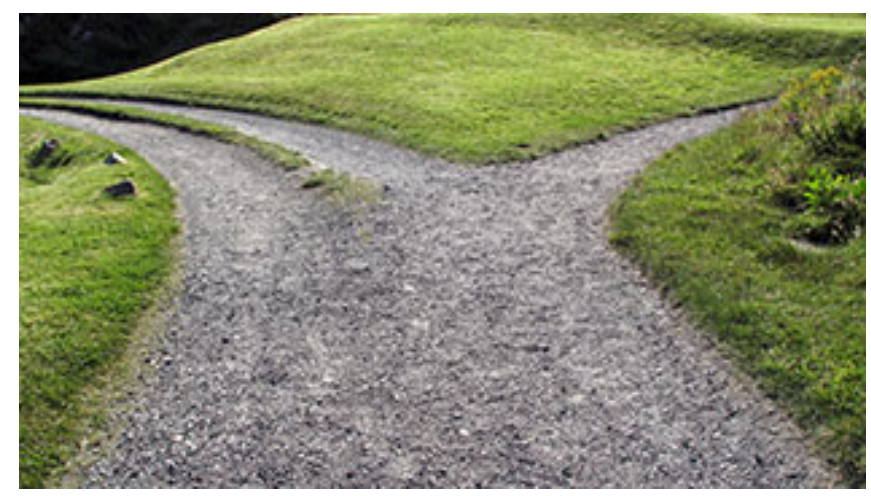

Figure 1: I Know Where I'm Going! (Mull), 2010

The choices we have and the decisions we make in consequence provided the major theme for my recent research projects. Accordingly, my creative fieldwork was divided into three parts, based on each other and offering an insight into my methodology: the first body of work, entitled I Know Where I'm Going!, arose from confrontation with choice. This is a significant basis for retrospec- 
tive considerations, which would be highly unlikely without the awareness of other options. ${ }^{6}$ Being confronted with choice and becoming aware of the necessity to choose is possible to explore using two-dimensional media, in this case photography and illustration. In the second series, Decisions - A User's Manual, three-dimensional objects and time-based media described the process, the difficulty and the various possibilities for decision making in different situations in life. And finally, this research was synthesised into concepts I categorise as "counterfactual art" executed example, directly based on my research into choice. In this work, immersion, interaction and the limitations of our perception serve as the most appropriate forms to represent the idea.

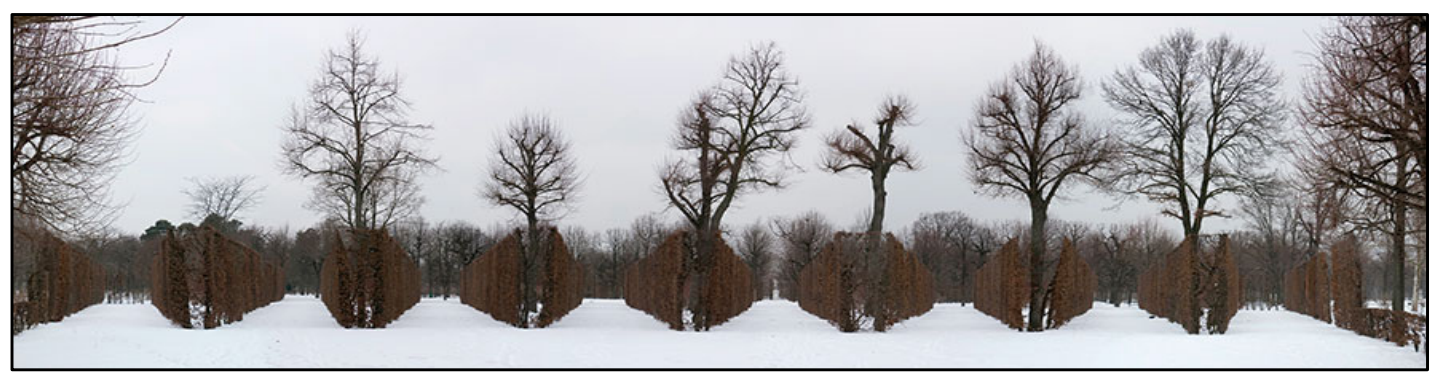

Figure 2: I Know Where I'm Going! (Schönbrunn), 2011

\section{Decidophobia}

The panoramic video installation Decidophobia consummates my interpretation of Argentinian writer Jorge Luis Borges's short story "The Garden of Forking Paths, ${ }^{18}$ which is the description of a fictional narration in which any of all possible futures can be chosen without eliminating any of the others. This leads to parallel, simultaneous times and universes in which all possible lives can be explored. In this scenario, counterfactual thoughts would be superfluous. In contrast, Decidophobia stimulates the awareness of the difficulty of choice. The surrounding voices doubt their choices and, if viewers fail to attend to the right place in the right moment, they might miss the words being spoken, which would immediately invite retrospective thoughts. 


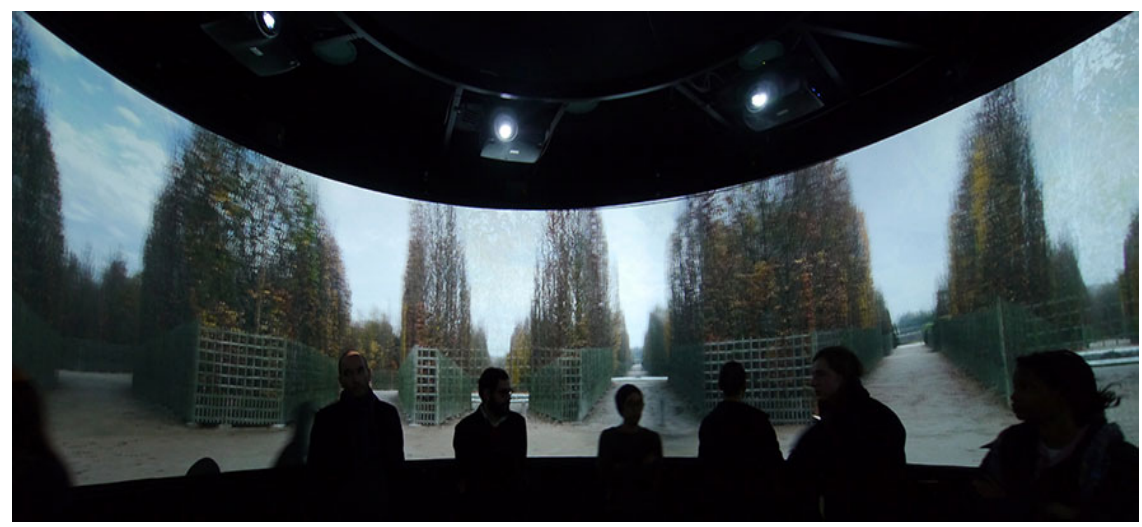

Figure 3: Decidophobia, 2012. Installation view, PanoramaLab ZKM, July 2012

A reference to the iconography of Hercules at the Crossroads ${ }^{9}$ as found in Renaissance paintings, can be observed as well. At the entrance to adulthood, the Greek mythological hero had to choose between two female representations, Vice and Virtue, representing two possible paths in life. His facial expression and body language show that he is pondering which is the right track to choose. In Annibale Carracci's ${ }^{10}$ painting from 1595, a steep and narrow path in the background indicates the virtuous path, the easier and wider path shows the way to vice. Although, I refrained from making any reference to these personifications or placing a value on the paths, the photographic series I Know Where I'm Going! relates directly to the depictions of this ancient myth.

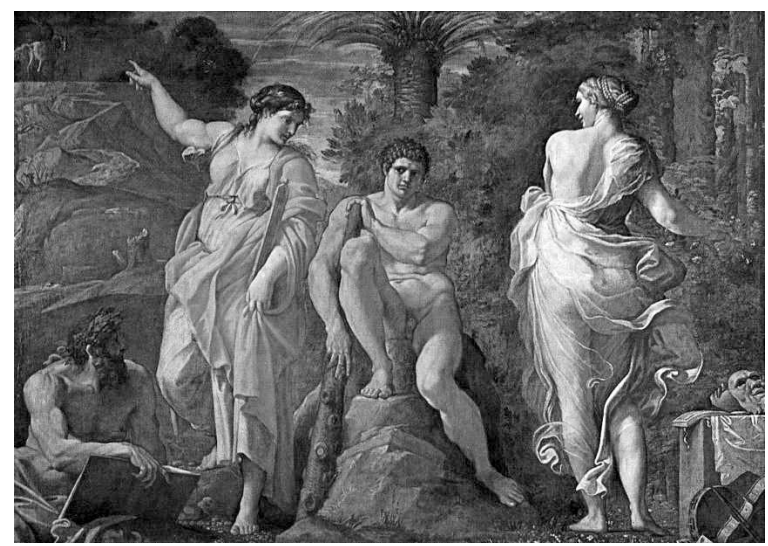

Figure 4: Annibale Carracci, Hercules at the Crossroads, 1596 
Decidophobia is based on these landscape images, with different forking paths ${ }^{11}$ resembling several possible choices. A perfect labyrinth completely surrounds the viewer. It is not possible to orientate oneself: paths appear, disappear and vanish completely, as new possibilities open up. A soundtrack underlines the visual experience and passers-by express their confusion by questioning where they actually are, where they should go to, which path to take, and where they have come from. The babel of voices in eight languages comes from different directions, adding to the confusion. It is difficult to focus on one voice, or a familiar language, which leaves the viewer with the impression of a missed conversation, a missed opportunity.

In this study, I will share insights into my attempt to immerse the spectator in the awareness of the luxury of choice, their freedom to choose and the suggestion that we can be satisfied with our options. The installation described is an approach to invite the audience to reflect on choices and decisions. The immersion in a $360^{\circ}$ environment provides an ideal framework to engage unknown spectators and trigger emotions.

\section{Material and Methods (The Challenge of Immersing an Audience in a Virtual Garden of Forking Paths)}

In my research on the visualisation of choice and the task of decision making, I drew my main source of inspiration not only from the visualisations of Hercules at the Crossroads, but from the reference to the letter, or rather symbol, " $Y$ " (also called the Pythagoræn letter). ${ }^{12}$

As a result, I considered common pathways as the best possibility for visual reference to different paths in our lives. I searched for the perfect structure, a maze or a labyrinth, ${ }^{13}$ with a complex and confusing series of tracks to symbolise the different possible paths in life. While labyrinths provide a linear meander from beginning to end, mazes offer the choice of a series of possibilities and - more interestingly - a number of traps or dead-end routes. 
Although mazes were mentioned in Greek mythology, I was particularly interested in the ones designed for Baroque and Rococo gardens. They were built for absolute sovereigns to enjoy the luxury of moving along perfectly trimmed pathways - getting lost on purpose, trying different routes, detours and side tracks. I was researching the potential for mazes to provide a visual metaphor for the network of decisions which we follow in our lives.

It was an engaging task - each forking path represented a kind of decision. I travelled to a specific location to explore what remains of well-pruned hedges and pathways: Zen gardens in Japan; the concrete paths of a botanical garden in Spain; hedge mazes in Great Britain; a rose-garden in the Czech Republic; winding alleyways in Italy and Israel; a Baroque maze in Austria; a corn maze in France; and labyrinths in several cathedrals and parks. Most of the mazes within parks were mentioned only in tourist guides, or found in etchings made in centuries past.

After several unrewarding journeys, I explored the locations beforehand from above, using satellite images. Again, the result was not as expected: hedge mazes that appeared beautiful on Google Earth ${ }^{14}$ were brown and leafless in reality; labyrinth-like structures were just painted on the ground; promising winding lanes were closed for the winter, and therefore not accessible, or had even been turned into building sites and were hidden behind scaffolds.

Arriving in Paris for a residency at Cité International des Arts, one of my first tasks was to visit the park at Versailles, although I knew that the once-famous maze, Bosquet du Labyrinth, ${ }^{15}$ which the French garden designers André Le Nôtre and Charles Perrault had created in the $17^{\text {th }}$ century, no longer existed. However, I was generously rewarded in my quest for forking paths. What I discovered was far more exciting than any maze-like confusion seen from above: although the map showed a well-organised grid which seemed easy to navigate, it turned out to be a perfect structure of forking lanes. The Bosquet de la Girandole in Versailles contains fourteen intersections and is mirrored on the other side of the park by a similar structure, called the Bosquet du Dauphin. The original plan, which has been reconstructed, was initially created between 1661 and 1663 by André Le Nôtre. ${ }^{16}$

ICONO14 | Año 2014 Volumen 12 N² 2 | ISSN: 1697-8293 | DOI: ri14.v12i2.714 

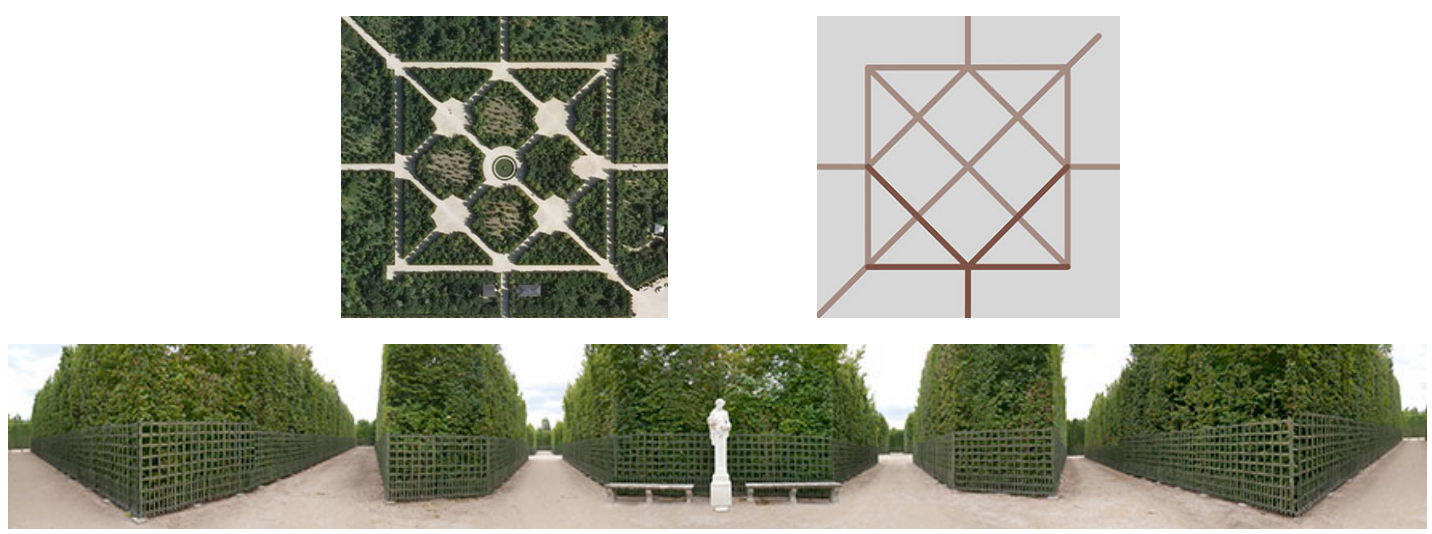

Figure 5: Above: Aerial view on Le Bosquet de Girandole, 2011; Map of Le Bosquet de Girandole, drawing, 2011; Below: Versailles, panorama photograph, 200 by 40 centimetres, 2011, as exhibited at Cité International, Paris, September 2011

The twenty-eight intersections look confusingly similar; however, they are distinguished by small details: some junctions are based on four, some on five crossroads, two on only three; some are symmetrical, other not so; one of them contains four white marble sculptures, two are adorned with one, while another one is graced by three sculptures. What might seem straightforward, is in reality a confusing matrix. The grey-beige pebble-stone paths are flanked by four-metretall, dense deciduous hedges, gleaming green in spring and summer, but brown in autumn and winter. Even leafless, the hedges do not allow a view through their tangled branches. There is no visible beginning or end: once inside, it is easy to lose orientation, and therefore difficult to find the preferred exit - the ideal environment for confronting an audience with a series of choices, and subsequently developing counterfactual considerations such as 'Where would the other paths have lead', and 'Why did I not try those?'.

\subsection{From the Idea to the Right Form}

In order to transfer the extraordinary feeling of being surrounded by many choices and unable to choose an easy way out, I captured the intersection that I regarded as most appealing photographically, in a style similar to that of the panoramic images in my research I Know Where I'm Going!, with an overcast sky. This provides ideal conditions, as it does not provide any orientation or preference; 
each path in the final picture possessed its own vanishing point. In change from the earlier series, I captured $360^{\circ}$ panoramic images, rather than covering a range of only $180^{\circ}$.

The dimensions of the printed image displayed in a show in Paris were 200 by 40 centimetres. The image was presented alongside a panoramic image of the same size, displaying a hedge maze in Barcelona. The impression inside the network of forking paths was overwhelming; flat on the wall, the result was slightly disappointing. For that reason, I considered other forms of presentation: a larger size or a slightly curved construction on which to mount the image and to make the work more immersive, in a manner similar to Claude Monet's extraordinary panoramic paintings Decorations des Nymphéas, which are located in purpose-built oval galleries, ${ }^{17}$ designed by the artist and completed in 1927.

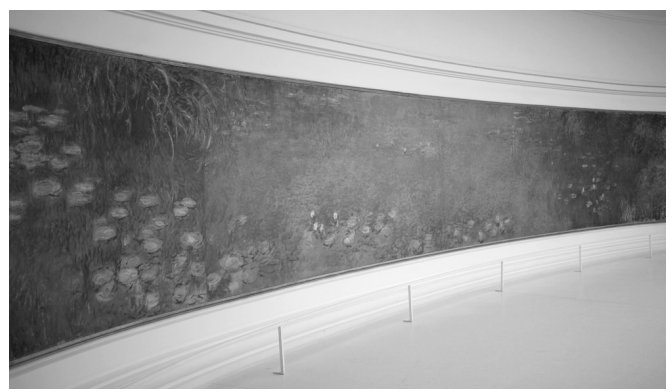

Figure 6: Claude Monet, Decorations des Nymphéas, 1927, Musée de l'Orangerie, Paris

My residency in Paris was followed by a scholarship to ZKM/HfG Karlsruhe ${ }^{18}$ where I had the privilege of experimenting in the immersive environment of the PanoramaLab. ${ }^{19}$ Here I discovered how perfectly the panoramic still of the Bosquet from Versailles worked as a panoramic projection, and how close it came to the actual feeling of being inside the gardens. I decided to develop a concept specifically for this immersive environment. The next time I returned to Versailles, the atmosphere had changed: the hedges were covered in autumn leaves of a uniform shade of brown, with only a few shrubs with vibrant shades of red and yellow. The captivating white sculptures were covered for the winter with a brownish-green fabric, which transformed them into mysterious objects. But the garden was still 
enchanting, and even more intriguing because the shrubs were not as dense as in summer, and their nearly bare branches were fascinating.

Back in the PanoramaLab, I decided to recreate the perception of the actual space on an emotional level: peaceful, relaxing, quiet, magical, but at the same time confusing and intimidating. For this reason, I continued to work with the panoramic still images I had captured at each of the fourteen intersections and fused them into a two-minute video.

In comparing the images from summer and autumn, it was difficult to choose between them; summer appeared dense and confined. Only the paths gave a view through the thicket and the colours were appealing, the green contrasting the beige of the ground perfectly. Although the space seemed more open in autumn, the colour scheme left a rather depressing feeling on the test-audience. I quickly came to the conclusion that it would be best to use the seasons in alternation, to provide the impression of a reappearing situation - exactly what counterfactual thinking is supposed to prepare us for: to be able to make better decisions in similar, recurrent situations. I reduced the selection of forking paths and converted them into more suitable geometric junctions, which do not exist in the garden itself. In addition, I used subtler, less obvious transitions in the edit.

While working in Europe on the project, I appreciated the changes in the annual cycle more than ever (after the perennial green of Sydney, Australia) and decided to complete the seasons, with winter and spring. The variations of atmosphere, moods and rituals had been an essential part of my life: the change of colours and sounds, the smell of the air, the hours of daylight.

The final version of the project is composed of all four seasons. In spring, tender green leaves appear; summer shows dense, green coverage of the hedges; autumn provides a brown structure; and finally, in winter everything looks bleak and is covered with a white, snowy veil - with the implied expectation of a new beginning in spring. This could be considered in juxtaposition to the concept of counterfactuals, and a connection to the eternal cycle. 
The title Decidophobia is a composite expression, containing the verb "to decide" and the noun "phobia", the latter meaning an extreme fear or aversion. In 1973, the American philosopher Walter Arnold Kaufman described the concept in detail and referred to Freud's study of unusual phobias. Kaufman mentions as well the closeness of the words "to decide" and "deciduous" - the name for plants that shed their leaves annually, from the Latin decidere, meaning "to fall down" or "to fall out at maturity" (for example, children's milk teeth). ${ }^{20}$

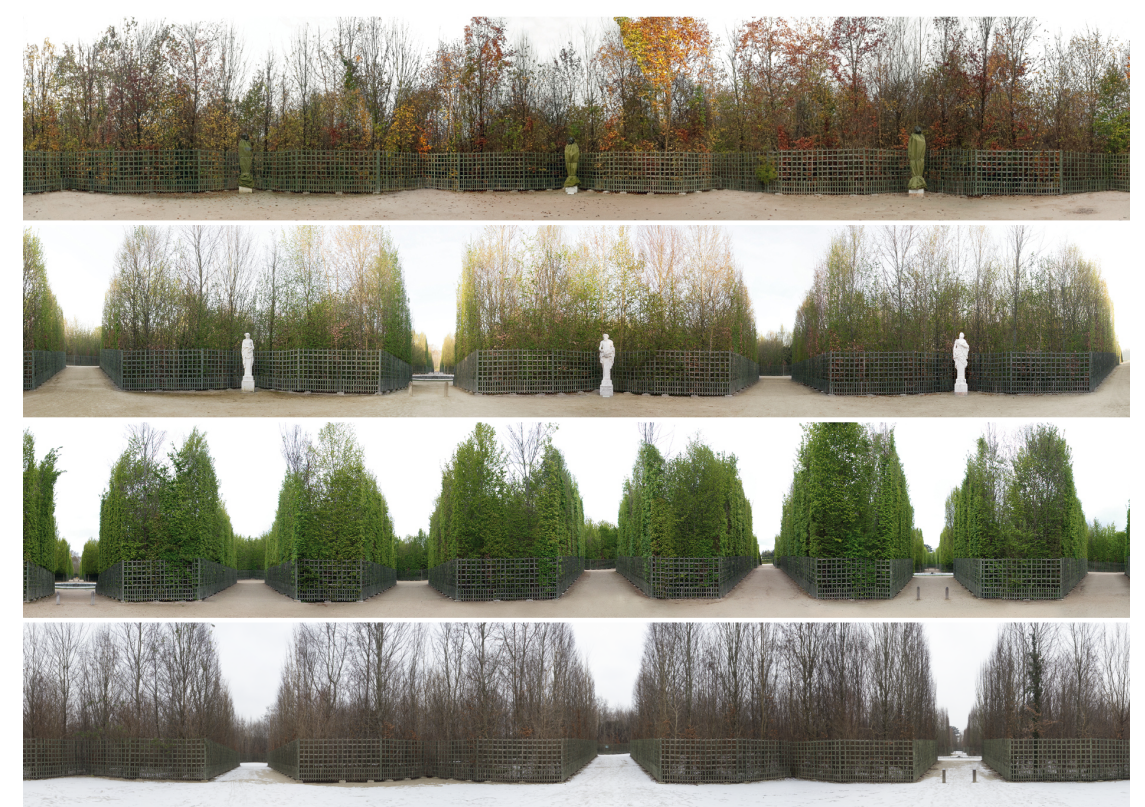

Figure 7: Decidophobia, 2012. Different versions of the paths in the annual cycle

The title is apposite, since I captured the annual cycle of the garden in reference to the eternal cycle, and at the same time the confrontation of too many options of similar-looking paths, causing disorientation. Leaving the observer unable to choose which direction to focus upon, the title matches the sentiment perfectly.

\subsection{Addressing Aural Senses}

The audio layer of Decidophobia both reveals and evokes counterfactual thoughts. It is retrieved from actual observations inside the Bosquet. 
Decidophobia - an Artistic Research on the Possibilities of Immersive Environments $\mid 218$

Coming to the grove as a frequent visitor, I overheard the reactions and conversations of others. Simply re-recording some of the actual conversations might appear to be an unambitious sound composition, but the expression of confusion proved to be the best metaphor for being confronted with seemingly equal choices in life - and in front of the network of paths in the park.

Which is the right path? Quel chemin est le bon?

Wo führt dieser Weg wohl hin?

Все пути похожи друг на друга.

We have been here before!

誰決めることです...

Elk pad ziet er hetzelfde uit.

Wohin jetzt?

Vogliamo tornare indietro?
Every path looks the same.

Waar gaan we nu heen?

Where will this road take us?

Die Wege sehen alle gleich aus.

¿Y ahora?
Let's go left and imagine what would've happened if we'd turned right.

Los caminos son todos iguales.

Wo sind wir hergekommen?

On été déjà ici! Where to?

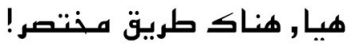

Shouldn't we rather go back?

Figure 8: An excerpt of questions spoken in different languages in Decidophobia

I started to record voices in nine languages: English, German, Chinese, French, Spanish, Russian, Polish, Czech and Japanese. The final composition is optimised for eight or sixteen speakers in a circular array. Female and male voices pose questions, often simultaneously, asking whether they are on the right track, whether they have been here before and other phrases expressing their confusion and as well their everyday counterfactual thoughts. The arrangement of many simultaneous voices alternates with pauses and phrases spoken in all languages successively. The so-called cocktail party effect ${ }^{21}$ draws attention to a familiar language, but soon after its appearance, the sound snippet vanishes and is heard coming from another direction.

The sound arrangements refer directly to my understanding of the confusion that is described in the myth of the Tower of Babel in the Old Testament. Humans were trying to build a tower reaching heaven. "The Lord said, 'If as one people speaking the same language they have begun to do this, then nothing they plan to do will be impossible for them $[\ldots]^{22^{\prime \prime \prime}}$. Therefore, according to the tale, God gave people many languages, so that a common understanding became impossible. 
Borges's short story The Babylon Lottery ${ }^{23}$ relates to that event. It seems to be about an infinite game of chance. The rules and methods are explained in detail. In the end the reader is aware that it is the lottery of life, with all our faith in destiny, which is played by a higher existence. Our whole life is determined by the draw of the lottery of the "big company."

All spoken questions in my work are posed in a manner that refers equally to forking pathways or to life-changing decisions. The soundscape is completed by ambient sounds in the background and accentuated by a specially recorded sound, the reversed clink of glasses - metaphorically a noise introducing a counterfactual element. Although theoretically possible, in reality, once broken, a glass cannot be reconstructed. The same is true of events in our lives - once a decision is made and we follow that path, it cannot be reversed.

The multi-channel audio layer requires the audience to move around, to become mobile spectators, and to explore an individual spatial composition based on their physical position and the point to which their attention is drawn. Adding studio reverb was attempted in order to simulate the different seasonal atmospheres, but could not accomplished to my full satisfaction and was therefore left out in the end.

An important reference to the audio layer of Decidophobia is the spatial acousmatic melodrama Forêt Profonde ${ }^{24}$ (Dark Forest) by contemporary French-Canadian composer Francis Dhomont. Based on Bruno Bettelheim's essay The Uses of Enchantment, it is a spatial journey through the childhood memories of fairy-tales. Dhomont's work plays with our reception of different languages and well-worn phrases ("Once upon a time...", "Es war einmal...", "Il était une fois...") with which he evokes traumatic memories of disturbing fairy-tales.

As the American artist Joseph Nechvatal mentioned in his book Immersion Into Noise, ${ }^{25}$ art and entertainment have merged. In order to stimulate the audience to think and reflect, it is necessary to avoid an immediately obvious spectacle - "it restores art's responsibility of resistance, ${ }^{26}$ an aspect which I consider applicable to Decidophobia.

ICONO14 | Año 2014 Volumen 12 N² 2 | ISSN: 1697-8293 | DOI: ri14.v12i2.714 


\section{Results and Discussion}

The immersive ${ }^{27}$ panorama screen proved the ideal presentational format. The cylindrical $360^{\circ}$ environment is a fixed installation at ZKM Karlsruhe and was developed in collaboration with the iCinema Research Centre ${ }^{28}$ in Sydney. It consists of six HD-projectors with a total aspect ratio of approximately 19:2. The size of the projection is 11012 by 1152 pixels in the rotunda with an eight-metre diameter and a height of 2.80 metres. This means that all of the peripheral vision is covered.
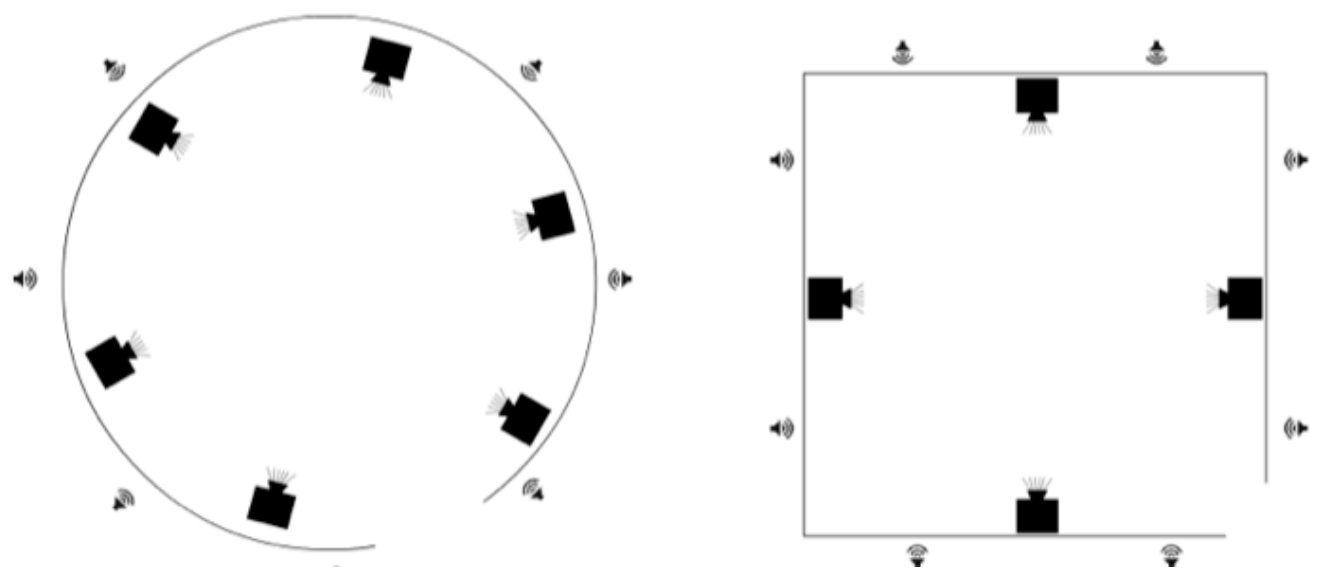

Figure 9: Installation set-up for $360^{\circ}$ environment and black cube

The video file was prepared in the required dimensions with a video compositing application, ${ }^{29}$ exported as a movie file and rendered to match the screen with dedicated software ${ }^{30}$ developed for the panorama screen by the ZKM Institute for Visual Media. "Zirkonium", customised software which distributes the audio file on eight channels, was also developed at ZKM, at the Institute for Music and Acoustics (IMA). Hearing the stereo sound, down-mixed as a documentation, can hardly replicate the actual experience of listening to eight channels inside the sound dome. Yet the same is valid for many artworks, and is true for the whole installation of Decidophobia.

DOI: ri14.v12i2.714 | ISSN: 1697-8293 | Año 2014 Volumen 12 № 2 | ICONO14 


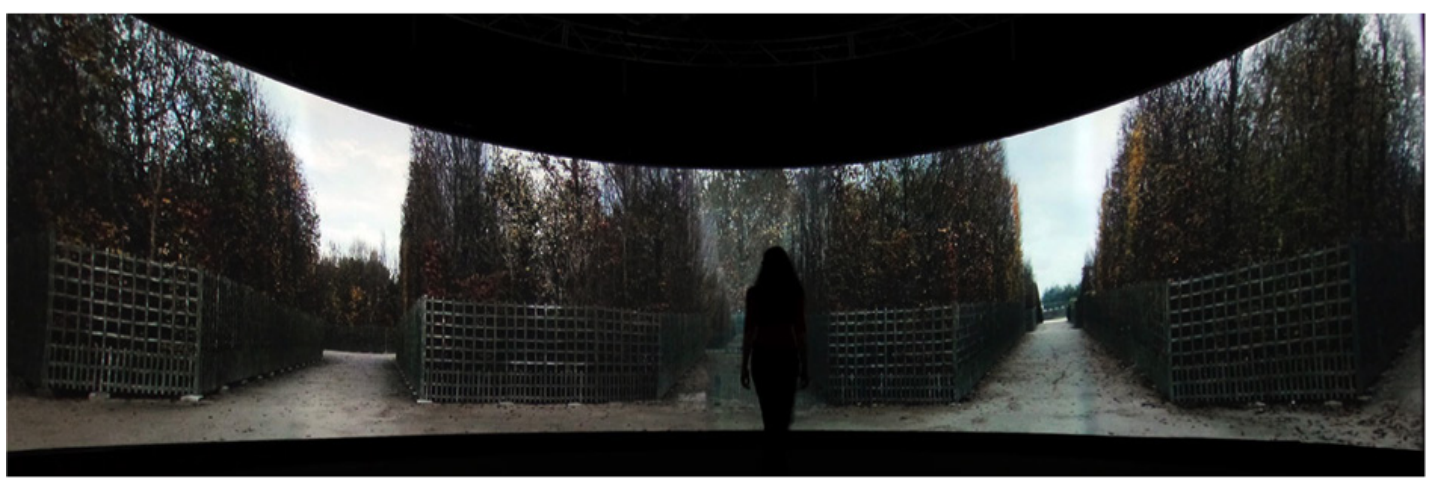

Figure 10: Decidophobia as presented at iCinema, UNSW Sydney

To date, Decidophobia has been displayed at the iCinema in Sydney and at the $360^{\circ}$ conference in Plymouth. The set-up differed hugely in the two venues. The permanently installed iCinema covers the sight completely: it reaches down to the floor and uses an aspect ratio of 8:1 with a larger diameter, though with a lower resolution. The immersive experience is more intense due to the fact that the horizon is not framed, but seems limitless.

The temporary wooden structure in Plymouth used a different array: five XGA-projectors in an even bigger space. Although the audience felt immersed, I was not satisfied with the brightness and clarity of the images. Because not many permanent set-ups, such as the ones in Karlsruhe, Sydney or Hong Kong exist and in particular not in an ordinary exhibition context, it is necessary to think about alternatives to the optimal installation.

\subsection{Substitutes for $360^{\circ}$ Environments}

During a studio show I experimented with a $90^{\circ}$ angle projection, covering two adjacent walls. The disadvantage is the loss of the feeling of being immersed, and what is even more problematic, the simultaneous vanishing points of all paths are less obvious and strangely confusing in the projection on a flat surface, which is broken by a corner. The same is true for a black cube set-up with a four-projector array distributed on four walls: due to the less realistic perspective, the feeling of immersion is not satisfactory.

ICONO14 | Año 2014 Volumen 12 NN$^{\circ} 2$ | ISSN: 1697-8293 | DOI: ri14.v12i2.714 


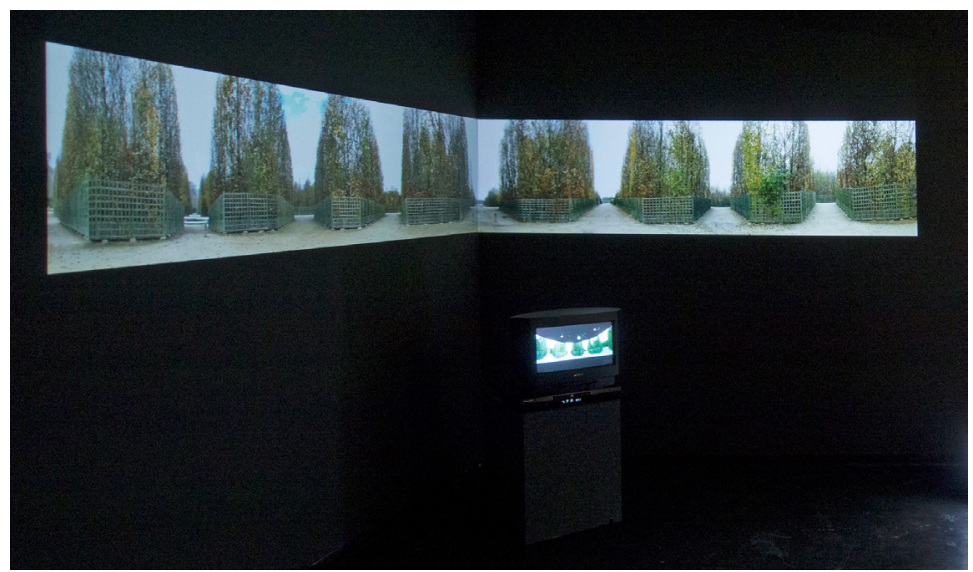

Figure 11: Decidophobia, alternative set-up for a studio visit, December 2012

Consequently, I considered a series of printed, large-scale photographs to be the best alternative to the curved screen of the immersive environment in another medium. As the origin of the expanded photography installation, the printed photograph is still valid. During a presentation in the PanoramaLab, I showed four prints simultaneously along a white wall, mounted on aluminium, each with dimensions of 300 by 50 centimetres and a matte surface. In some respects, the printings are reminiscent of Chinese scrolls ${ }^{31}$ - not packed with multiple layers of information, like the narrative visual scrolls by Dutch artist Tjiebbe van Tjien, ${ }^{32}$

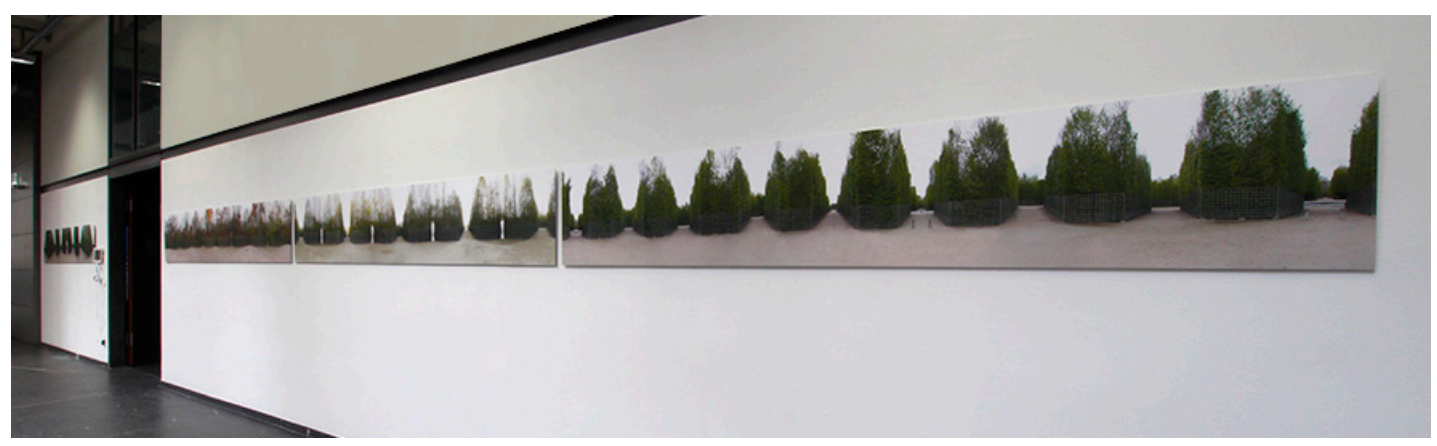

Figure 12: Decidophobia, photographs on alu-dibond, 4 panels, 300 by 50 centimetres each, installation view at HfG, July 2012

but modestly stimulating reflections and emotions. Mounted without frames on the wall, the panoramic images accompanied the members of the audience as they 
walked a distance of twelve metres through the different seasons. Viewing the images from a distance brought the initial intention of the panoramic print back to life. The multiple vanishing points, which had been amended in the editing process, achieved a degree of subconscious confusion - Where to focus? - while the viewer was walking towards the series of images.

In order to make the work more accessible, I explored one further approach, by creating a virtual reality panorama ${ }^{33}$ which linked all the variations of intersections and seasons, including the audio. Obviously, the advantage is in the versatility: it can be seen anywhere, at anytime, on a smartphone, tablet, computer screen or as a gigantic projection. Although this technique resembles that of video games, the participant in this case is trapped forever in the labyrinth of forking pathways. After the initial struggle to escape and reach another level, the user is supposed to capitulate, through the changing seasons and repetitive pattern of pathways, to the eternal recurrence. When playing games, we can usually go back to the last saved level or start over again. In real life, we rarely have the chance to do so and, even if we do, we might lack time and energy. With this application, we can instantly experience what we missed on the path we didn't take, but we also have to accept that any chosen path just leads to another array of forking roads.

Nevertheless I consider the presentation on a flat screen, ${ }^{34}$ without the inclusion of peripheral vision, as an immense loss to the project. One positive is the supplementary interactivity, and more direct confrontation with the question of choice, finally leading to the surrender of the quest for a goal, or the return to another path, to be replaced by the appreciation of the moment, the here and now.

\subsection{Alternative Themes}

Regarding the metaphor of visualisation, the question might be asked, why did I not focus on the illustration of trees, with their trunks, boughs, branches and the veining of their leaves as a reference to all the possible paths our life can take? The French/Chinese artist Ma Chong ${ }^{35}$ built a tree out of drainage-system plastic pipes, which expanded over two floors, describing the changes in his artistic life. The context he provides, however, is not in the ramification of the tree, but the tradi-

ICONO14 | Año 2014 Volumen 12 N² 2 | ISSN: 1697-8293 | DOI: ri14.v12i2.714 
tional Chinese way of studying, the necessity of learning to draw a tree flawlessly, and conversely, away from the mainland, the urge to experience the freedom to build a tree in whatever material. Nevertheless, the resulting structure could easily be compared to the possible alternatives that we encounter in our lives.

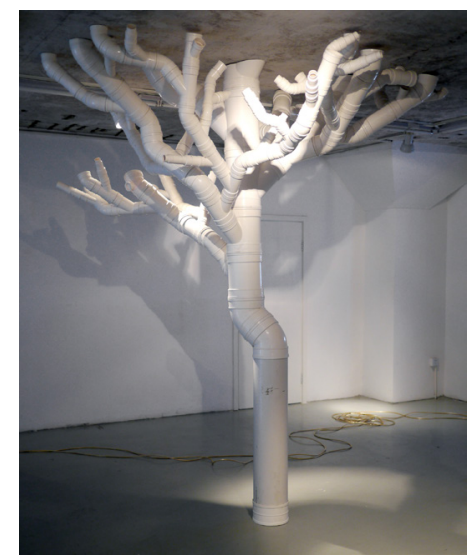

Figure 13: Chong Ma, Tree, Shanghai Biennale, 2012

Another work visualising this structure of consequences is The Small Knocking Down the Big by Qiu Zhijie. ${ }^{36}$ It is a giant domino installation with many branches and a trunk comprised of increasingly large stones. An interesting aspect is the direction of the domino effect. During a performance at the Venice Biennale in 2009, the artist initiated the movement from the small peripheral stones, which fell towards the big "root" stones in order to make them collapse - a task which was not achieved.

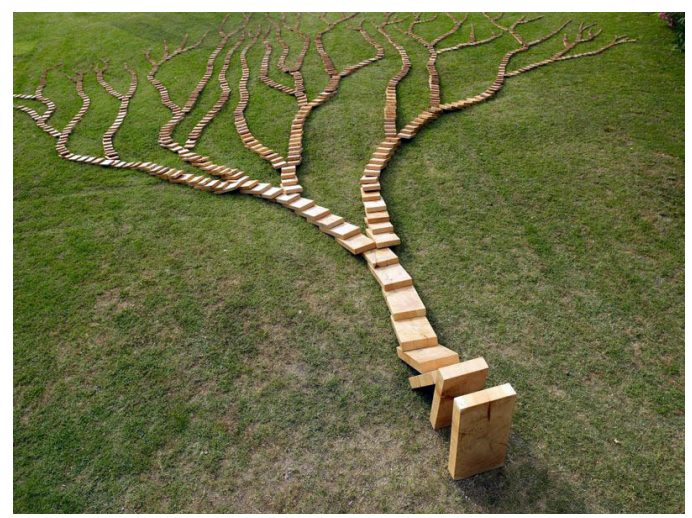

Figure 14: Qiu Zhijie, The Small Knocking down the Big, Venice Biennale 2009

DOI: ri14.v12i2.714 | ISSN: 1697-8293 | Año 2014 Volumen 12 № 2 | ICONO14 
The concepts mentioned above connect to different aspects of life, particularly to lifelines. Nevertheless there is a simple reason why I did not apply these structures to my praxis, which becomes obvious in my earlier research for Decision Making Taxonomy - forking paths as seen from above compared to the paths at eye level. The structure of a tree provides an overview, but it does not incorporate the actual task of deciding at a particular branching point. The same is true of the Pythagoræn letter Y: rather than standing at the crossroads itself, we observe from a distance how the line splits into two possible alternatives. There is a linear path until the bifurcation at the cusp of adulthood, often referred to in literature and visualisations. The structure of the tree can display the path of a whole life, but in fact we face one intersection at a time, as David Bordwell ${ }^{37}$ observed in his essay on forking path narrations.

Another approach, which I did not pursue, was a split-screen movie in which all the paths I came across would fork endlessly and continue in parallel until they all reached a common destination. Explored as a stop-motion-movie, the screen was firstly bisected and continued to bifurcate further into smaller segments of the screen: a scene with a fork in the road split vertically, then, at the next intersection horizontally, and so on until multitudinous tiny movies were running simultaneously. During the production process, I remembered Dieter Kiesling's interactive application Continue. It repeatedly poses a question about the continuation of the process, a rational choice until the squares are too small to be recognised and provide an entirely random choice. Astrid Sommer describes it as follows:

“Yes or No? 0 or 1? Quit or Continue? Infinity is, in fact, limited: a pixel is the smallest, indivisible unit of the digital image, and when the threshold has been exceeded in which "Quit" is allocated to every second pixel and "Continue" to the others, then only random operations remain, as opposed to further multiplications."

Continue consists of a division between black and white that makes it visually appealing and attractive, whereas the forking paths proved to be too detailed and the result was merely confusing. Therefore I abandoned this approach as well, although in theory it would have been a suitable way to present the concept of

ICONO14 | Año 2014 Volumen 12 N² | ISSN: 1697-8293 | DOI: ri14.v12i2.714 
counterfactualism: experiencing all the paths which we were not able to take simultaneously, while at the same time being unable to appreciate one of the single paths in the overwhelming multitude.

\subsection{Result}

To conclude, in light of my observations and experiences, panoramic environments provide ideal conditions for the physical and cognitive experience of a mobile spectator who is encouraged to interact with the surroundings by turning around and moving through the space.

In my understanding, as encountered during the screenings, people often make a connection between forking paths and the difficulty of choosing. In particular, in the moment when all paths disappear and a closed wall of hedges covers the screen, followed by new paths opening up, causes by far the most intense impression. The audience feels the agony of choice, the difficulty of deciding in which direction to look; but it is perceived to be much worse to have no choice at all, to be trapped in closed surroundings. Not everyone on our planet has the freedom of choice, for reasons that include cultural background, society and status.

The panoramic projection, in this case $360^{\circ}$, covered the peripheral vision and beyond. This means that, although there is no dramatic action, the spectators are always aware that something might be occurring behind their backs. In addition, the sound composition enhances this impression, mainly on a subconscious level, with fragments of recognisable sentences that shift as they move through the immersive environment.

With this research, I came to understand the importance of an appropriate technique for expressing my intentions, even those dependant on an elaborate set-up, and realised the significance of immersion, including vision, sound and spatial experience, for an artwork that directly addresses specific emotions in an unknown audience. 


\section{Notes}

[1] Reinhuber, E. (2014). Counterfactuals in Media Arts. In K. Ng \& J. Bowen \& S. McDaid (Eds.) EVA London, 2014: Electronic Visualisation and the Arts (pp. 98-99). London: BCS, The Chartered Institute for IT.

[2] Ferguson, N. (ed.). (1999). Virtual History. Alternatives and Counterfactuals. New York: Basic Books.

[3] Kahneman, D., \& Miller, D. (1986). Norm Theory: Comparing Reality to its Alternatives. Psychological Review 93, pp. 136-153.

[4] DeWitt, B. (1970). Quantum Mechanics and Reality: Could the Solution to the Dilemma of Indeterminism Be a Universe in Which All Possible Outcomes of an Experiment actually 0ccur? Physics Today 23, 9, pp. 155-165.

[5] Mandel, D., \& Hilton, D., \& Catellani, P., (Eds.). (2005). The Psychology of Counterfactual Thinking. London: Routledge, Chapman \& Hall.

[6] Markman, K., \& Miller, A. (2006). Depression, Control and Counterfactual Thinking: Functional to Whom? Journal of Social and Clinical Psychology 25.2.

[7] Reinhuber, E. (2013). Counterfactualism - a new category for fine arts and humanities, dealing with the retrospective analysis of turning points in life (Unpublished doctoral dissertation). The University of New South Wales, College of Fine Arts, Sydney, Australia

[8] Borges, J. (1999). The Garden of Forking Paths (El Jardín de senderos que se bifurcan). [1941]. In J. Borges, Ficciones. London: Bristol Classic Press.

[9] Panofsky, E. (1930). Hercules am Scheidewege . Und andere antike Bildstoffe in der neueren Kunst. Berlin: Gebr. Mann.

[10] Ibid.

[11] The popular example of the Choice of Hercules (cf. Prodicus, loc. cit. Xenophon (1923) The Memorabilia . Book 2. In E. C. Marchant, (Ed.). Xenophon. (vol. 4) London: William Heinemann, Ltd.) presents Hercules as personification of strength and courage at a crossroad, uncertain which way to choose. The personifications of Virtue and Vice tempt him to follow the two paths: the hard, steep and rocky path leading to glory, or the wide and easy one, guiding him to a comfortable, pleasant life, but also into perdition. His body and face show the struggle between the two temptations. From the myth of Hercules, I adapted the iconography of crossroads into my work and transferred the quest for an ideal forking path to visualise the difficulty of choice.

[12] The Littera Pythagoræ, the Samian letter or more common - the letter $Y$ is in my regard the simplest way to visualise an intersection with two paths to choose from, if it is not just seen as a letter. The German philologist Wolfgang Harms (Harms, W. (1970). Homo viator in bivio. Studien zur Bildlichkeit des Weges. München: Wilhelm Fink.) assumed that the letter Y was only ascribed to Pythagoras by his followers and disciples. 
[13] Kern, H. (2000). Through the Labyrinth: Designs and Meanings over 5000 Years. München: Prestel, p. 23.

[14] My initial research for this artwork took place in 2009/10, when Google Street-View did only provide a main road perspective.

[15] Thompson, I. (2006). Sun King's Garden: Louis XIV, André Le Notre and the Creation of the Gardens of Versailles. London: Bloomsbury Publishing, pp. 133-141.

[16] Ibid., pp. 105, 160.

[17] Musée de l'0rangerie in the Tuileries, Paris.

[18] Baden-Württemberg-Stipendium by courtesy of the Baden-Württemberg-Stiftung to study at HfG Karlsruhe University of Arts and Design.

[19] Centre for Art and Media, Karlsruhe.

[20] Kaufman, W. (1973). Without Guilt and Justice: From Decidophobia to Autonomy. New York, NY: P. H. Wyden, p. 273.

[21] Bronkhorst, A. (2000). The Cocktail Party Phenomenon: A Review on Speech Intelligibility in Multiple-Talker Conditions. Acta Acustica united with Acustica 86.1.

[22] Genesis 11:4-9, vid. (2011) Holy Bible, New International Version. BibleGateway.com. Retrieved from <www.biblegateway.com/>, 10.07.2014. Genesis 11:9 That is, Babylon; Babel sounds like the Hebrew word for "confused".

[23] Borges, J. (1993). Ficciones. London: David Campbell Publishers Ltd., p. 45.

[24] Dhomont, F. (1996). Forêt profonde. France, Canada. Retrieved from <http://www.electrocd. com/en/oeuvres/select/?id=14329> <http://www.digital-music-archives.com/webdb2/application/Application.php?ProductCode=CDE0045>, 10.07.2014.

[25] Nechvatal, J. (2011). Immersion Into Noise. Ann Arbor, MI: University of Michigan - Open Humanities Press.

[26] Ibid., Preface, pp. 9-12.

[27] Grau, 0. (2003). Virtual Art: From Illusion to Immersion. Cambridge, MA: MIT Press.

[28] Research \& Development: Interactive High Resolution Panorama. (n. d.). Karlsruhe: ZKM | Zentrum für Kunst und Medientechnologie. Retrieved from <http://on1.zkm.de/zkm/stories/storyReader $\$ 5310>, 10.07 .2014$.

[29] Adobe $^{\circledR}$ After Effects ${ }^{\circledR}$ CS4.

[30] Panorama Display Software [PDS].

[31] For instance a remarkable example is the famous scroll of "Along the River During the Qingming Festival (清明上河圖)", painted by Zhang Zeduan in the early $12^{\text {th }}$ century with the dimensions of $25.5 \mathrm{~cm} \times 525 \mathrm{~cm}\left(10^{\prime \prime} \times 207^{\prime \prime}\right)$, Palace Museum, Beijing. Retrieved from <http://www.nytimes.com/2007/07/03/arts/design/03pain.html?ei=5090\&en=1d3319aaf35b6c1b\&ex=1341115200\&partner=rssuserland\&emc $=r s s \& p a g e w a n t e d=a l l \& \_r=0>, 10.07 .2014$.

DOI: ri14.v12i2.714 | ISSN: 1697-8293 | Año 2014 Volumen 12 N² 2 | ICONO14 
[32] Tjebbe van Tijen explores different techniques and presentations of scrolls over three decades. An overview can be found on the web; cf. Tijen, T. (n. d.). Imaginary Museum. Retrieved from <http://imaginarymuseum.org/>, 10.07.2014.

[33] That originates from the classic QTVR-application (Quick Time Virtual Reality) by Apple and makes panoramic photographs interactively accessible, with an option to scroll through the captured environment. Hotspots link to other panoramic images or close-ups or even activate audio. QTVR is not well supported nowadays, therefore most VR-applications utilise Adobe ${ }^{\circledR}$ Flash, JAVA, HTML5, or are custom built.

[34] LG announced in January 2013 the production of a curved screen in order to include peripheral vision, the EA9800, cf. LG's curved EA9800 OLED display eyes-on. (2013, January $8^{\text {th }}$ ) engadget.com. Retrieved from <http://www.engadget.com/2013/01/08/lgs-curved-ea9800oled-display-eyes-on/>, 10.07.2014.

[35] Personal conversation with the artist at the Shanghai Biennale, 2012, October $18^{\text {th }}$.

[36] Seen at Venice Biennale 2009; cf. Zhijie, Q. (2009.) The Small Knocking Down the Big. 53rd Venice Biennale, Giardini. Retrieved from <http://www.qiuzhijie.com/worksleibie/zhuangzhi/e-duominuo.htm>, 10.07.2014.

[37] Bordwell, D. (2002). Film Futures. SubStance 31, 1. Retrieved from <http://www.jstor.org/ stable/3685810>, 10.07.2014. 